\title{
Study of Biogas Production from Cassava Industrial Waste by Anaerobic Process
}

\author{
Budiyono $^{1,{ }^{*}}$, Arindra D. Primaloka ${ }^{1}$, Listi Ardhannari ${ }^{1}$, Hashfi H.A. Matin ${ }^{2}$, and Siswo Sumardiono ${ }^{1}$ \\ ${ }^{1}$ Department of Chemical Engineering, Engineering Faculty, Diponegoro University, 50275 Semarang, Indonesia \\ ${ }^{2}$ Master Program of Environmental Science, School of Post Graduate Studies, Diponegoro University, 50275 Semarang, Indonesia
}

\begin{abstract}
Biogas production processes from tapioca wastewater have several problems that cause the biogas production is not optimal, such as $\mathrm{pH}$ drop at beginning of the process because the rate of acid formation is too fast and the rate of starch wastewater degradation is too slow. Therefore, to obtain optimal biogas production it is required two-stage reactor. The purposes of this research were to (i) study the influence of one stage fermentation and two stage fermentation on biogas production, (ii) study the effect of buffer $\mathrm{Na} 2 \mathrm{CO} 3$ on biogas production, and (iii) study the effect of methanogenic bacteria concentration on biogas production from cassava starch effluent. The first method of our research was hydrolysis process by "Saccharomyces cereviceae" as substrate activator. The second is the arrangement of $\mathrm{pH}$ and the last is process of methane production. The results showed that the highest biogas production is achieved at concentration of methanogenic bacteria $20 \%(\mathrm{v} / \mathrm{v})$ that is equal to $2458 \mathrm{ml}$. At concentration of $8 \%(\mathrm{v} / \mathrm{v})$ and $15 \%(\mathrm{v} / \mathrm{v})$, biogas production was $2105 \mathrm{ml}$ and $2117 \mathrm{ml}$. The addition of $\mathrm{Na}_{2} \mathrm{CO}_{3}$ can extend to 16 days with accumulation of $372 \mathrm{ml}$. While without the addition of buffer, biogas production period was only 9 days with accumulation of $620 \mathrm{ml}$. In semi continuous process, the analysis carried out every 3 days. Highest biogas production achieved in the variable addition of yeast with the accumulation $9329 \mathrm{ml}$. Without yeast, accumulation of biogas was $6831 \mathrm{ml}$. Yeast is use as substrate activator so it can accelerate the hydrolysis process and increased biogas production. The addition of $\mathrm{Na}_{2} \mathrm{CO}_{3}$ is increase the alkalinity so the $\mathrm{pH}$ drop did not occur early in the process.
\end{abstract}

Corresponding author: budiyono@live.undip.ac.id 


\section{Introduction}

In the processing of cassava into wet tapioca starch, the tapioca miss rate that comes with wastewater during deposition slurry process slurry is large enough. It's about $1 \%$ of total cassava tapioca [1] which directly lost upon environment. Large contain of tapioca in these wastes can be used as raw material for biogas making.

The process of biogas production from tapioca wastes have several problems that led the biogas production not optimal, among others, the $\mathrm{pH}$ drop at beginning process because the rate of acid formation is too fast that causing death of microbial methanogens. Besides that, slow degradation rate of tapioca waste caused by the solids content of tapioca waste is still a polysaccharide molecule. Therefore, to obtain optimal biogas production need two stages reactor. The first stage is hydrolysis to produce simpler saccharide compounds (disaccharide and monosaccharide) by Saccharomyces cereviceae. The second stage is formation of methane from the output of first reactor by methanogens bacterial. Meanwhile, $\mathrm{pH}$ drop in early process can be prevented by $\mathrm{Na}_{2} \mathrm{CO}_{3}$ which acts as buffer to maintain the $\mathrm{pH}$. With the addition of $\mathrm{Na}_{2} \mathrm{CO}_{3}$ and the hydrolysis of polysaccharides is expected to produce a lot of biogas in a short time. Similar with tapioca, many researchers have conducted research on biogas from waste such as agricultural waste is able to produce a lot of gas through an anaerobic process [2$12]$.

In general, the purpose of the study was to evaluate biogas production with two-stage fermentation of waste water from tapioca industrial with substrate activator. Specifically, the purpose of the research was to study the effect of anaerobic microbial concentration on the rate of biogas formation, study the effect of $\mathrm{Na}_{2} \mathrm{CO}_{3}$ buffer addition on the rate of formation of biogas, study the effect of fermentation 1 stage and 2 stage in rate of biogas production from starch waste.

\section{Materials and Methods}

Materials used in the experiment is synthetic wastewater of tapioca manufacture that made by mixing 20 grams of tapioca in 2 litters of water. Yeast (Saccharomyces cereviceae) NKL brand. Water is obtained from Chemical Process Laboratory, Chemical Engineering, Diponegoro University. Urea was obtained from the Waste Treatment Laboratory, Chemical Engineering, Diponegoro University, and Buffer $\mathrm{Na}_{2} \mathrm{CO}_{3}$ non-PA obtained from chemical shops in Semarang.

The tools used in the experiments is a two-stage anaerobic biodigester which consists of waste and nutrient storage tank, mixing tank, airtight stirred tank, airtight stirred tank and pressure resistant, $\mathrm{pH}$ meters, water pump, valve, pipe, pressure gauge, hose with diameter $1 \mathrm{~cm}, 250 \mathrm{ml}$ measuring cup, water tank, and electric motors. Overall design of equipment used is presented in Figure 1.

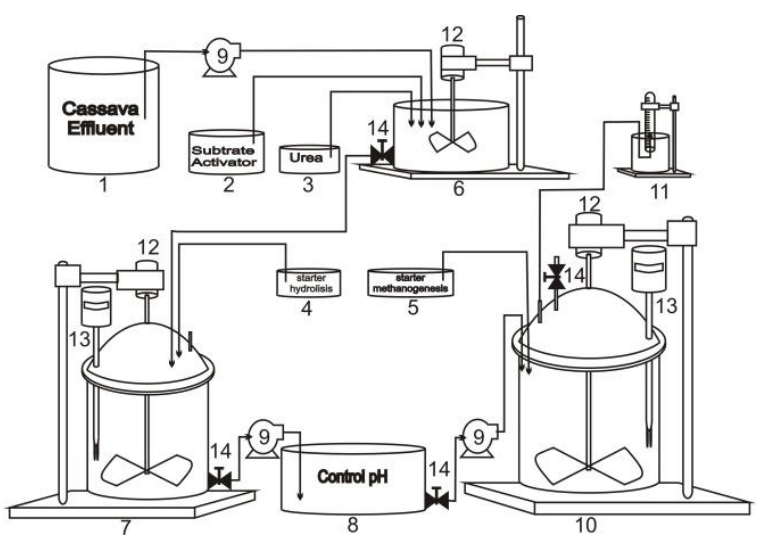

Fig 1. Equipment Design

The fixed variables tested to several respond variables. These variables include: fermentation 1 stage and 2 stage in continuous conditions with $\mathrm{Na}_{2} \mathrm{CO}_{3}$ buffer, rumen concentration is $10 \%(\mathrm{v} / \mathrm{v})$, and yeast. In two stage fermentation, when yeast variables of 0.08 $\mathrm{w} / \mathrm{v}$, the rumen concentrations is $8 \%, 15 \%$, and $20 \% \mathrm{v} / \mathrm{v}$. When yeast variables of $0.15 \% \mathrm{w} / \mathrm{v}$, the addition of $\mathrm{Na} 2 \mathrm{CO} 3$ buffer is batch with variables the presence or absence of and rumen concentration of $15 \%(\mathrm{v} / \mathrm{v})$ and yeast $0.15 \%(\mathrm{w} / \mathrm{v})$ in batch conditions.

The process begins by assembling the equipment like in Figure 1. Then mix the tapioca wastes $1 \%(\mathrm{w} / \mathrm{v})$ with $0.4 \%$ urea $(\mathrm{w} / \mathrm{v})$. In the second stage of fermentation the mixture is then poured into hydrolysis tank and then add the Saccharomyces cerevisiae $0.08 \%$ $(\mathrm{w} / \mathrm{v})$, and let stand for 1 day, so polysaccharides will be degraded into disaccharides and monosaccharides. Furthermore disaccharide and monosaccharide produced in hydrolysis tank flowed by pumped to the $\mathrm{pH}$ regulator tank. The tank was in the range of $\mathrm{pH} 7$ using $\mathrm{Na}_{2} \mathrm{CO}_{3}$, and then pumped it into biogas formation tank. In this biogas formation, disaccharide and monosaccharide was mixed with methanogenic microbial starter $10 \%(\mathrm{v} / \mathrm{v})$ and tapioca wastewater as substrate of $100 \mathrm{ml}$ every 12 days.

Basic experimental of 1 stage and 2 stage fermentation be the same. In 1 stage fermentation, the wastes directly neutralized with buffer and mixed with rumen bacteria with a concentration of $10 \%(\mathrm{v} / \mathrm{v})$ without yeast, one of its $\mathrm{pH}$ tank is not regulated and without addition of substrate, and in each tank was added rumen bacteria with different concentration of $8 \%, 15 \%$, $20 \%$ (v/v) without addition of substrate.

Test results were carried out by analysis amount of methane by using a water displacement technique, temperature and $\mathrm{pH}$ measurements was carried out every day. Observations were made continuously until the methane was not formed anymore.

\section{Results and Discussions}

Biogas is produced depends on composition of feed material. Organic materials that can be used as raw material for biogas production are animal waste, solid waste, sewage sludge, etc. This study used tapioca 
wastewater with batch and semi-continuous processes. Characteristics of the biogas produced in each process are described below. Experiments were carried out to raise the levels of $\mathrm{C} / \mathrm{N}$ of 2 liters tapioca waste water tapioca $1 \%(\mathrm{w} / \mathrm{v})$ in each tank with urea $0.4 \%(\mathrm{w} / \mathrm{v})$. Experiments with rumen concentration $(8 \%, 15 \%, 20 \%$ $\mathrm{v} / \mathrm{v})$, yeast concentration $0.15 \%(\mathrm{w} / \mathrm{v})$, with $\mathrm{Na}_{2} \mathrm{CO}_{3}$ buffer batch in 2 stage fermentation system obtained the following results in Figure 2.

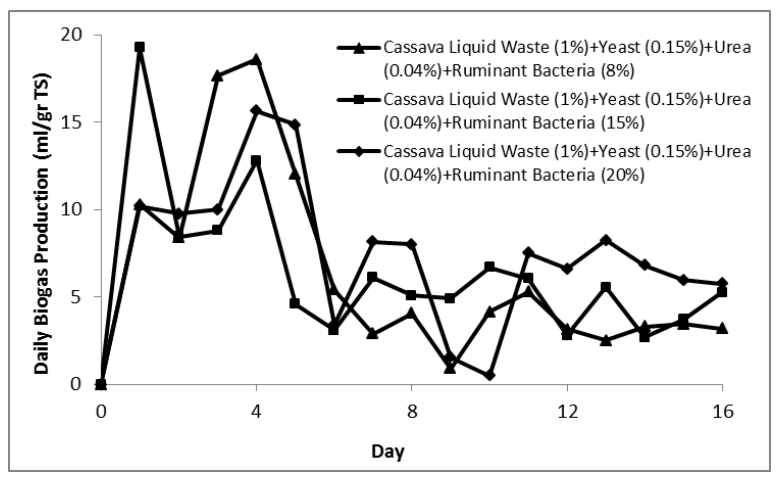

Fig 2. The Effect of Substrate Activator to Biogas Production

Figure 2 describes the relationship of methanogenic bacteria (rumen) concentration in anaerobic fermentation process. It can be seen that the daily biogas production rate is best obtained when the addition of methanogenic bacteria by $8 \%[1,13]$. This is due to the process of biogas production with tapioca waste material optimum obtained when the number of methanogenic bacteria by $20 \%$.

Bacteria which first worked out in the process of changing such complex carbohydrate polymer is cellulolytic bacteria or other hydrolytic bacteria. Cellulolytic bacteria break or cut the cellulose molecule, the molecule with high weight into cellulobiose (glucose) and free glucose. Glucose is then fermented anaerobically to produce a variety of fermentation products such as acetate, propionate, butyrate, $\mathrm{H}_{2}$ and $\mathrm{CO}_{2} \cdot \mathrm{H}_{2}$ results from primary fermentation immediately used by methanogenic bacteria (methanogens) which is the last bacteria used in anaerobic fermentation process. In addition, it is also required for the conversion of acetate to methane in anaerobic fermentation by some methanogenic bacteria.

At this stage of methane gas formation, methanogens bacteria plays the role. Methanogens bacteria will utilize the results of second stage, such as formats, carbon dioxide, and hydrogen as substrates to produce methane, carbon dioxide, trace of gases such as $\mathrm{H} 2 \mathrm{~S}$ and water. Data shows that the highest accumulation of biogas production obtained when addition of $20 \%(\mathrm{v} / \mathrm{v})$ methanogenic bacteria is $2458 \mathrm{ml}$ or $122.9 \mathrm{ml} / \mathrm{g}$ TS. While the production of biogas for variable concentrations of methanogenic bacteria by $8 \%$ $(\mathrm{v} / \mathrm{v})$ and $15 \%(\mathrm{v} / \mathrm{v})$ are $2105 \mathrm{ml}$ or $105.25 \mathrm{ml} / \mathrm{g}$ TS and $105.85 \mathrm{ml}$ or $2117 \mathrm{ml} / \mathrm{g}$ TS. Biogas production on addition of $20 \%(\mathrm{v} / \mathrm{v})$ methanogenic bacteria is lower in the beginning of process than the addition of $15 \%(\mathrm{v} / \mathrm{v})$ methanogenic bacteria. It happened until the fourth day. The characteristics of resulting curve above in accordance with growth curve of bacteria which consisting of four stages, such as lag stage, exponential stage, logarithmic stage, stationary stage, and death stage.

Methanogens bacteria growth in the beginning of process is still going through adjustment to the raw material circumstances in which will be broken down into the biomass, in terms of nutrients, $\mathrm{pH}$, or temperature that corresponds to its place. Furthermore, these bacteria will experience rapid growth process that will produce maximum biogas because the use of good nutrition by methanogens bacteria. The next stage, bacteria begin lack of nutrition in which the number of bacteria that grow as much as the bacteria die so that the biogas produced is relatively constant (fixed). And at the end of the fermentation process the bacteria have started to die, so that biogas production has begun to decline.

There are five generation of methanogenic bacteria that play a role in the formation of methane, namely: Methanobacterium, Methanobacillus, Methanopyrales, Methanococcus, and Methanosarcina. Methanogens bacteria are the most important bacteria in the decomposition anaerobic process. This bacterium is a group of organisms that are very sensitive to oxygen and $\mathrm{pH}$ changes in the medium. Bacterial growth rate was slower and more sensitive to changes in the environment when compared with bacterial non-methanogens. Special ability of these bacteria is to remove the excess electrons in an effective way by converting hydrogen into methane which causes the hydrogen concentration in medium remained low. It is important for the presence of cytogenesis bacteria and ultimately led the decomposition process can continue effectively [14].

In the process of anaerobic fermentation for biogas formation used cow rumen as microbes decomposer. There are three groups of bacteria that play a role in anaerobic fermentation, such as:

1. Polymers and monomers bacteria decomposer contained in the waste material and produces mainly acetate and hydrogen, and a number of volatile fatty acids like propionic, butyric and alcohol.

2. Acetogenic obligate bacteria produced hydrogen that covert propionate and butyrate become acetate and hydrogen.

3. Groups of methanogenic bacteria producing methane from acetate or hydrogen.

The final product of cellulose decomposition e by cellulolytic bacteria were succinate, acetate, format or butyrate. Below is a chart of $\mathrm{pH}$ and temperature characteristics at various feed composition for variable addition of methanogenic bacteria.

From Figure 3-5, it can be seen that for variable concentrations of methanogenic bacteria (rumen bacteria) showed that in the tank I have temperature range between 27 to $31.20 \mathrm{C}$, tank II between 26 to $32.50 \mathrm{C}$, and tank III between 26 to $33.8^{\circ} \mathrm{C}$. From the graph above can be seen temperature fluctuates in each tank for each variable with different ranges. All temperature range is still in the mesophilic temperature range between $28-45^{\circ} \mathrm{C}$. In addition to mesophilic temperature, anaerobic fermentation process can also occur in the thermophilic temperature, in temperature 
range $45-65^{\circ} \mathrm{C}$. When the temperature decreased, the activity of microorganisms also decreased so that the production of biogas will be decreased.

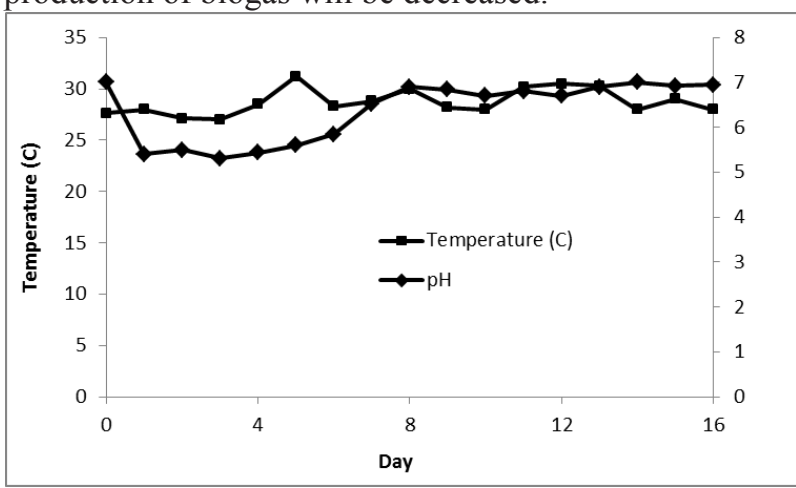

Fig 3. Methanogenic Bacteria Concentration of $8 \%$

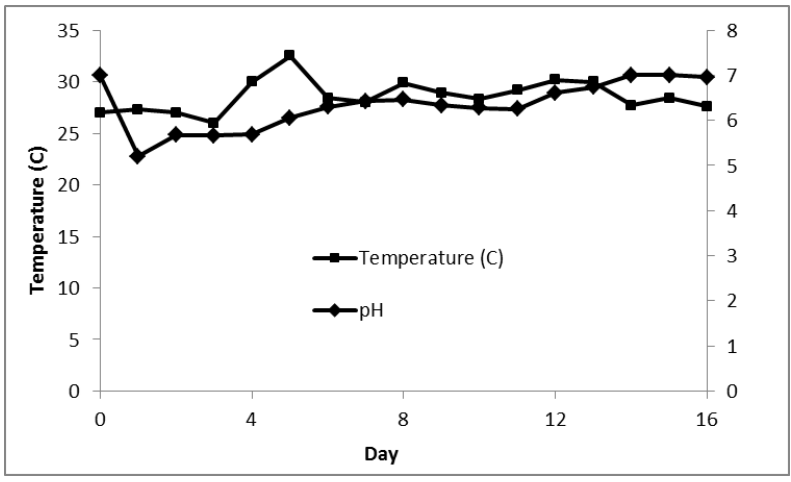

Fig 4. Methanogenic Bacteria Concentration of 15\%

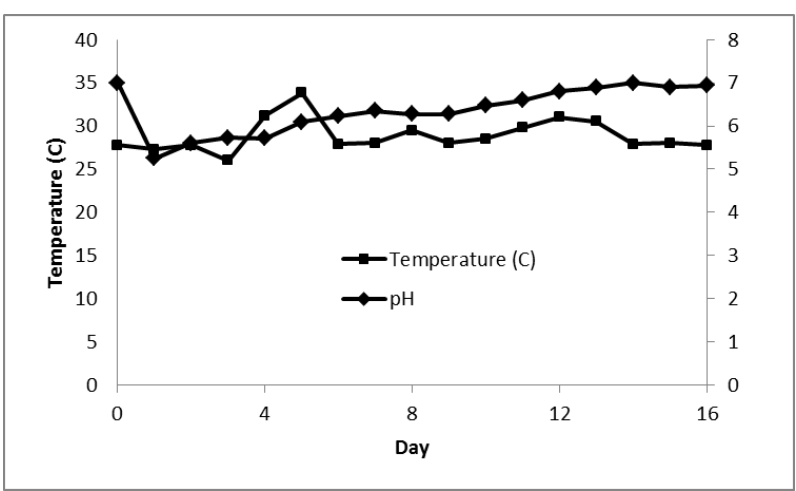

Fig 5. Methanogenic Bacteria Concentration of 20\%

In the terms of $\mathrm{pH}$, it can be seen that for variable concentrations of methanogenic bacteria (rumen bacteria) showed that for tank I have $\mathrm{pH}$ range between 5.31 to 7 , tank II between 5.2 to 7 , and tank III between 5.26 to 7 . At initial fermentation, acid-forming bacteria will produce acids that can quickly cause $\mathrm{pH}$ drop. That acid formation will produce acetic acid, $\mathrm{H}_{2}$ gas, and some VFA, such as butyric acid and propionate. When the $\mathrm{pH}$ value is low, the microorganisms will be in-active state in order to influence the rate of biogas formation, especially methanogenic bacteria. However, it can be handled with the addition of $\mathrm{Na}_{2} \mathrm{CO}_{3}$ buffer to improve its alkalinity. Methanogenic bacteria were able to grow well in $\mathrm{pH}$ range from 6.8 to 7.2 [15]. A good relationship between asidogenesis and methanogens stage is in neutral $\mathrm{pH}$ (7) and no dramatically increase in acidity and alkalinity [16].

From Figure 4 above can be seen that the addition of $\mathrm{Na}_{2} \mathrm{CO}_{3}$ buffer is different each day on each tank. In the tank I, the highest addition buffer is 3.13 grams that achieved on fourth day. Tank II, the highest addition of buffer is 4 grams which occurred on first day. This is because in those days, the $\mathrm{pH}$ in the tank II was drop quite dramatically, reaching 4.97 so that the required buffer is much to return it to neutral $\mathrm{pH}$ of around 7 . While for the tank III, the highest buffer addition is 3.65 grams on first day. In this tank,on first day already showed $\mathrm{pH}$ drop reached 5.35.

The addition of $\mathrm{Na}_{2} \mathrm{CO}_{3}$ buffer every day is different on each tank. This is because the $\mathrm{pH}$ drop in each tank also vary every day. Tank with high $\mathrm{pH}$ drop will require a lot of buffer, and vice versa. In experiment in variable with or without addition of $\mathrm{Na}_{2} \mathrm{CO}_{3}$ buffer in 2 stage batch fermentation obtained following results in Figure 6.

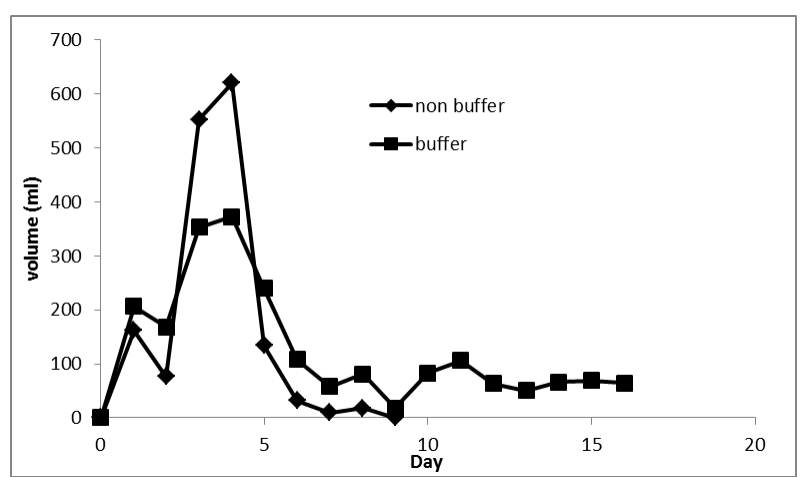

Fig 6. The Effect of Buffer Na2CO3 to Biogas Production

Figure 6 describes the effect of buffers on the rate of biogas formation. It can be explained that the production of biogas by using buffer $\mathrm{Na}_{2} \mathrm{CO}_{3}$ much less than not using buffer. On day 4 , the process of biogas formation by using buffers on feed achieving the highest number of $372 \mathrm{ml}$ with microbial life during 16 days. Rapid formation of acid can cause a number of methanogens bacterial be dead because it is not resistant to acidic conditions. In this case, using $\mathrm{Na}_{2} \mathrm{CO}_{3}$ aims to maintain $\mathrm{pH}$ range so bacteria can survive longer.

While fermentation without buffer, the biogas production is $620 \mathrm{ml}$. In this $\mathrm{pH}$ rumen bacteria have died because the life span of methanogens bacterial was lowest at $\mathrm{pH} 5$, so it can be concluded that the gas methane was not formed, but $\mathrm{CO}_{2}$. Cessation of biogas production is due to the $\mathrm{pH}$ getting down ( $\mathrm{pH}$ drop) until it reaches 4 . These $\mathrm{pH}$ conditions cause all the organisms die, so the biogas production ceased.

Figure 7 shows that the highest accumulation of biogas production obtained on the addition of buffer $2117 \mathrm{ml}$ or $105.85 \mathrm{ml} / \mathrm{g}$ TS. On the $3^{\text {rd }}$ day of biogas production on fermentation with buffer less rapidly with fermentation without buffer, this is because the gas generated in variable without buffer is not $\mathrm{CO}_{2}$ but methane. At this time the $\mathrm{pH}$ of medium was around 4-5 which optimum $\mathrm{pH}$ for yeast growth is. It happened until the $9^{\text {th }}$ day. However, in variable with addition of buffer 
has higher accumulation. The addition of buffer resulted $\mathrm{pH}$ medium is in the range of methanogens bacteria growth, so biogas production can continue until the substrate discharged on 16th day. In variable without buffer the production stopped 9th day. This is due to all microbes die because the $\mathrm{pH}$ is too low.

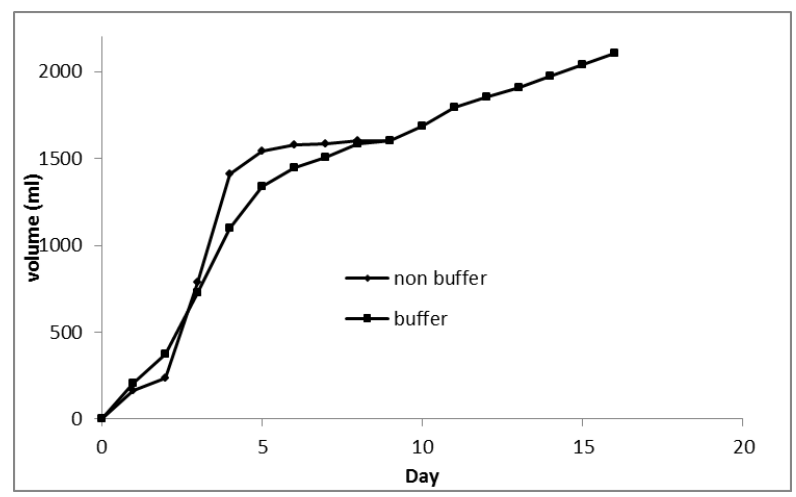

Fig 7. Accumulaton of Biogas Production (ml/gr TS) in Variable with Addition of Buffer and Without Addition of Buffer

In semi-continuous process, which is the feed pumped into tank I consists of $1 \%(\mathrm{w} / \mathrm{v})$ tapioca waste, urea $0.04 \%(\mathrm{w} / \mathrm{v})$, and rumen bacteria $10 \%(\mathrm{v} / \mathrm{v})$. Tank 2 consists of tapioca waste $1 \%(\mathrm{w} / \mathrm{v})$, urea $0.04 \%(\mathrm{w} / \mathrm{v})$, yeast $0.08 \%(\mathrm{w} / \mathrm{v})$, and rumen bacteria $10 \%(\mathrm{v} / \mathrm{v})$. The addition of 8 grams tapioca waste fresh feed done every 12 days.

Figure 8 shows that tank I consist of tapioca waste $1 \%(\mathrm{w} / \mathrm{v})$, urea $0.04 \%(\mathrm{w} / \mathrm{v})$, and rumen bacteria $10 \%$ $(\mathrm{v} / \mathrm{v})$. Biogas production rate in tank I is still inferior to tank II that consist of tapioca waste $1 \%(\mathrm{w} / \mathrm{v})$, urea $0.04 \%(\mathrm{w} / \mathrm{v})$, rumen bacteria $10 \%(\mathrm{v} / \mathrm{v})$, and yeast $0.08 \%$ $(\mathrm{w} / \mathrm{v})$. The peak of production in tank II reached on $3 \mathrm{rd}$ day that is equal to $625 \mathrm{ml}$, while tank I was on 6 th day that equal to $642 \mathrm{ml}$. It is because the tank II hydrolyse polysaccharide molecules into simpler molecules is faster with the help of Saccharomyces cerevisiae. So that the substrates used by methanogens bacterial is substrate with a shorter chain so that the process is also more rapid degradation. Therefore, biogas production rate in the tank II is faster than tank I.

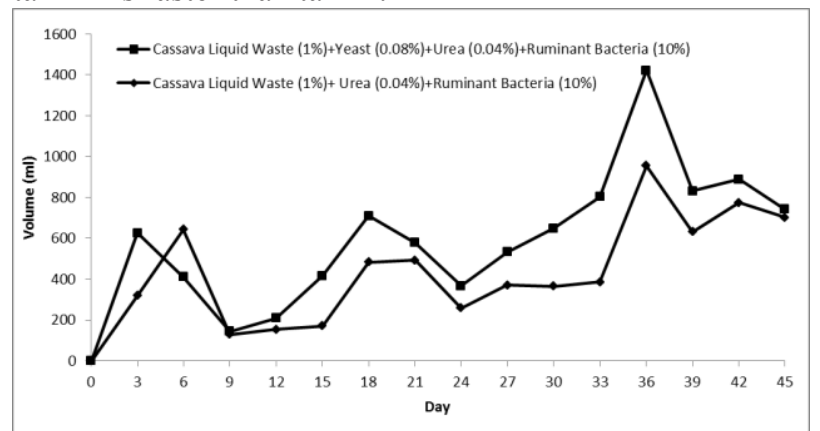

Fig 8. Daily Biogas Production (ml) on Vary Feed Composition

The addition of fresh feed 8 grams tapioca every 12 days can increase the rate of biogas production. It was seen in tank 1 and tank II on day 12 without addition of 8 grams tapioca, the biogas produced only $154 \mathrm{ml}$ in the tank I and $209 \mathrm{ml}$ in tank II. On day 15 with addition of
8 grams tapioca can be seen that production rises equal to $170 \mathrm{ml}$ in tank I and $416 \mathrm{ml}$ tank II but then fell again on day 21. Increased of biogas production is due to the fresh feed able to adding a substrate that will be fermented to produce biogas. Even so, the increase in biogas production occurs only to a certain value, after that it will be decline. That is because the substrate has been exhausted. The decreased biogas production can also caused by environmental factors, especially $\mathrm{pH}$ and temperature.

Figure 9 showed the accumulation of biogas production in vary feed composition variable. It can be seen that the accumulation of biogas production in tank 2 is higher than in tank 1. It happens because in the tank 2 contained of yeast (Saccharomyces cereviceae) which acts as substrate activator. Substrate activator can increase the rate of biogas production because it can speed up hydrolysis process by hydrolytic fermentative bacteria that produce simpler compounds for methanogens bacterial substrate. Total production of biogas in tank 1 is $6831 \mathrm{ml}$ or $155.25 \mathrm{ml} / \mathrm{g} \mathrm{TS}$, and in tank II is $9329 \mathrm{ml}$ or $212.02 \mathrm{ml} / \mathrm{g}$ TS.

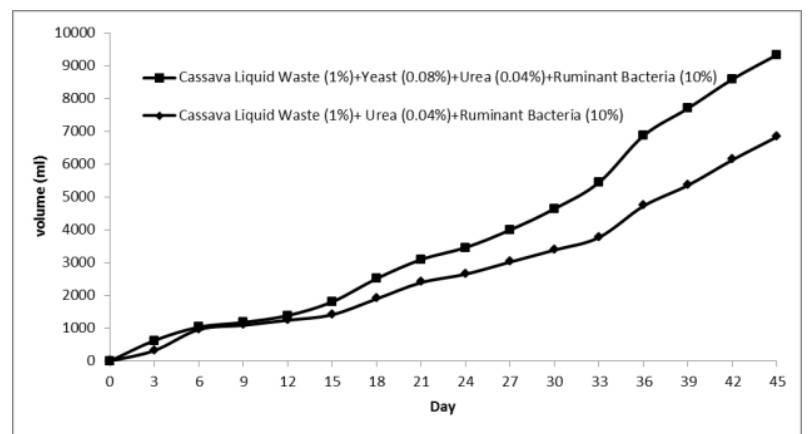

Fig 9. Accumulation of Biogas Production (ml) in Vary Feed Composition

From Figure 10 can be seen that for variable concentrations of methanogenic bacteria (rumen bacteria) showed that tank 1 has $\mathrm{pH}$ range between 4.8 to 7, tank 2 between 4.6 to 7 . At the time of initial fermentation, acid-forming bacteria will produce acids quickly that caused rapid $\mathrm{pH}$ decline. The acid formation will produce acetic acid, H2 gas, and some VFA, such as butyric acid and propionate.

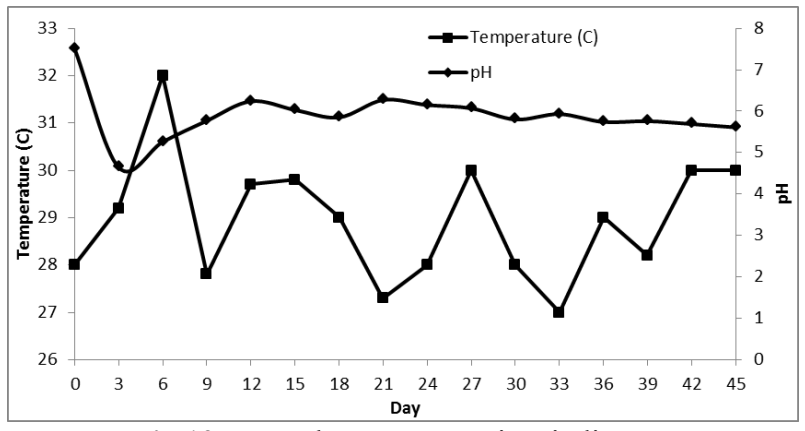

Fig 10. $\mathrm{pH}$ and Temperature in Biodigester

Bacteria were first worked out in the process of changing complex carbohydrate polymer is cellolulitic bacteria or other hydrolytic bacteria. Glucose is then fermented anaerobically to produce variety of fermentation products such as acetate, propionate, 
butyrate, $\mathrm{H}_{2}$, and $\mathrm{CO}_{2} . \mathrm{H}_{2}$ resulted from primary fermentation immediately used by methanogenic bacteria which is the last bacteria used in the anaerobic fermentation process. In addition, acetate is also needed for conversion to methane in anaerobic fermentation by some methanogenic bacteria. On the other hand, methanogenic bacteria were able to grow well by addition of buffer solution to increase its alkalinity. The addition of buffer used if the $\mathrm{pH}$ drop was above 1 . Magnitude of the addition of $\mathrm{Na}_{2} \mathrm{CO}_{3}$ buffer varies in each tank.

The growth rate of the acid-forming bacteria run faster than the growth of methanogenic bacteria, so the population of methanogenic bacteria is not sufficient to consume the amount of acid production. Excess of acid production in the beginning of the process could lead decrease in $\mathrm{pH}$ significantly to below $\mathrm{pH}$ neutral $(\mathrm{pH}=$ 7). It causes the growth rate of methanogenic bacteria is reduced. However, it can be handled with the addition of $\mathrm{Na} 2 \mathrm{CO} 3$ buffer to improve its alkalinity. Methanogenic bacteria were able to grow well on the medium that was initially in range of $\mathrm{pH} 6.8$ to 7.2 with a $\mathrm{pH}$ drop is not greater than 1 [16]. From Fig. 10 can be seen that $\mathrm{pH}$ drop was greater than 1 at day 21. Good relationship between asidogenesis and methanogens stage is currently in a state of $\mathrm{pH}$ drop below 1 , because in this state methanogens bacteria do not die in acidity medium levels that drop too fast.

In terms of temperature, from Fig. 10 can be seen that for the variable concentrations of methanogenic bacteria (rumen bacteria) in biodigester has temperature range between $28-30^{\circ} \mathrm{C}$. The temperature fluctuates in each tank for each variable with different ranges. All of the temperature range is still in the mesophilic temperature range, it is between $28-45^{\circ} \mathrm{C}$. When the temperature is decreased below $28^{\circ} \mathrm{C}$, the microorganism activity decreases which resulting in decreasing biogas production. However, when the temperature rose again, microbial activity will takes place as it should.

\section{Conclusions}

Biogas production is determined by the concentration of rumen bacteria, the addition of $\mathrm{Na}_{2} \mathrm{CO}_{3}$ buffer, and the type of fermentation. Greater concentration of rumen will increase accumulation of biogas production because there are more decomposer and rate of acid formation could be offset by formation of methane. The addition of $\mathrm{Na}_{2} \mathrm{CO}_{3}$ buffer able to providing biogas production period longer and the volume of biogas was greater than without addition of $\mathrm{Na}_{2} \mathrm{CO}_{3}$ buffer because $\mathrm{pH}$ drop in early process can be prevented. More complex fermentation type (2-stage) produce more biogas volume due process hydrolysis is faster.

\section{Acknowledgments}

Authors thank to Department of Chemical Engineering, Diponegoro University for all facilities to do this research.

\section{References}

1. Soemarno. Rancangan Teknologi Proses Pengolahan Tapioka dan Produk-Produknya (2007)

2. Budiyono, Syaichurrozi, I., \& Sumardiono, S. World Applied Sciences Journal, 26(11), 14641472 (2013)

3. Budiyono, Syaichurrozi, I., \& Sumardiono, S. International Journal of Engineering, Transactions B: Applications, 27(2), 177-184 (2014)

4. Budiyono, Syaichurrozi, I., \& Sumardiono, S. Research Journal of Applied Sciences, Engineering and Technology, 7(13), 2798-2805 (2014)

5. Budiyono, Wicaksono, A., Rahmawan, A., Hawali Abdul Matin, H., Gumilang Kencana Wardani, L., Djoko Kusworo, T., \& Sumardiono, S. Paper presented at the MATEC Web of Conferences, 101 (2017)

6. Shitophyta, L. M., Budiyono, \& Fuadi, A. M. Paper presented at the AIP Conference Proceedings, 1699 (2015)

7. Sumardiono, S., Budi Riyanta, A., Hawali Abdul Matin, H., Djoko Kusworo, T., Jos, B., \& Budiyono. Paper presented at the MATEC Web of Conferences, 101 (2017)

8. Sumardiono, S., Budiyono, \& Mardiani, D. T. Paper presented at the AIP Conference Proceedings, 1699 (2015)

9. Syafrudin, Dwi Nugraha, W., Hawali Abdul Matin, H., \& Budiyono. Paper presented at the MATEC Web of Conferences, 101 (2017)

10. Syafrudin, Nugraha, W. D., Ardinata, I. H., Kencanawardhani, L. G., Matin, H. H. A., \& Budiyono. Advanced Science Letters, 23(3), 22042206 (2017)

11. Syafrudin, Nugraha, W. D., Matin, H. H. A., \& Budiyono. Advanced Science Letters, 23(6), 56985700 (2017)

12. Syafrudin, Nugraha, W. D., Matin, H. H. A., Kencanawardhani, L. G., \& Budiyono. Advanced Science Letters, 23(6), 5687-5690 (2017)

13. Anunputtikul, and Wantanee. Suranaree University of Technology, Thailand (2004)

14. Adams, K. H. ASEAN Seminar-Workshop on Biogas Technology. Manila (1981)

15. Anunputtikul, W., and Rodtong, S. Abstracts of the 15th Annual Meeting of the Thai Society for Biotechnology and JSPS-NRCT Symposium. Thailand, p.70 (2004)

16. Anunputtikul, W., and Rodtong, S., The Joint International Conference on "Sustainable Energy and Environment (SEE)", 1-3 Desember 2004. Hua Hin, Thailand (2004). 